\title{
Community Participation in the Program Alert Village People in Kampung Keluarga Berencana (Kampung KB) Pataruman District, Banjar City
}

\author{
Mustofa Kamil*, Ace Suryadi, Purnomo, Dadang Yunus, Cucu Sukmana \\ Community Education Department \\ Indonesia University of Education \\ Bandung, Indonesia \\ *mustofa.kamilun@upi.edu, acesuryadi@upi.edu,purnomo@upi.edu, dadangyunus@upi.edu,cucusukmana@upi.edu
}

\begin{abstract}
The Kampung KB program is one of the innovations of the National Population and Family Planning Agency (Badan Kependudukan dan Keluarga Berencana Nasional, BKKBN) in Indonesia since 2014 in providing integrated services to the community, namely integrating population issues, economic welfare, public knowledge, public health, politics and other aspects. The aim is none other than to overcome the problem of population growth which is increasing and which results in obstruction of the pace of national development in various fields. This program is directed at democratization and decentralization, namely by encouraging community participation or involvement towards an independent society. The research was conducted using a qualitative approach to the case study method in Dusun Cigadung, Karyamukti Village, Paturaman District, City of Banjar. This village has received an Innovative Government Award in the field of public service of the Ministry of Home Affairs. The results illustrate the construction of a participatory model in forming a population alert village through the Kampung KB program.
\end{abstract}

Keywords-family planning (Keluarga Berencana, KB), community development, society participation

\section{INTRODUCTION}

Empowerment and participation are two different concepts, but they are closely related to development. The National development program is currently directed at democratization and decentralization which is oriented towards community participation in the planning process to evaluation of development programs [1,2]. The importance of the community's capacity aims to increase its independence and internal capabilities for all its resources $[3,4]$. So, a model like this is very important in the empowerment process by building community initiatives to achieve independence and development goals. Some research results explain that empowerment will not be optimal if a participatory approach is not applied, and vice versa, participatory is part of the community empowerment component itself [5-11].
Community empowerment is basically a process to empower society. Every member of society in a community actually has the potential, ideas and abilities to bring himself and his community to a better direction, but that potential sometimes cannot develop due to certain factors. In order to revive community independence in development in its community, initial encouragement or ideas are needed to revive its role and position in the framework of building civil society.

However, in reality building civil society is not an easy process. Population problems, such as increasing population growth, hamper the pace of national development in various fields. The contribution of the National Population and Family Planning Board (BKKBN) to population problems is very historic. Prior to 1970 , the implementation of family planning services was developed through a personal approach, considering that at that time the Indonesian government had not yet approved the idea of family planning, so that at that time family planning was still an individual only among middle and upper middle families. Over time with various approaches, BKKBN has attempted to encourage community participation in the family planning (family planning) program. Until 2014 until now, BKKBN has played a strategic role in encouraging the implementation of integrated services, namely services that are not provided by one party or only one health unit. As people who live in certain areas with various population problems, family welfare problems, family health problems and the environment as well as community knowledge, it is a circle that is interconnected between education, health and the economy. This means that to accelerate the resolution of these problems, BKKBN innovates by implementing an integrated (integrative) and comprehensive program approach based on area through the innovative program of Kampung KB.

The implementation of Kampung $\mathrm{KB}$ in West Java Province has contributed to overcoming population problems, including: 1) Provincial population growth in West Java has increased, from 2010 to 2016 , namely an average population growth of 600,000 people [12] ; 2) The population of West Java province is the largest in Indonesia, namely $18.28 \%$ of the 
total population in Indonesia, while other provinces range in the range of $0.34 \%$ to $5.46 \%$ [13] ; 3) The population density in West Java Province is quite high, this is because the population is driven by the number of births and urbanization from other areas; and 4) High youth rates, shown by the pyramid shape of the young population (expansive).

In West Java Province, there is a high birth rate and a low mortality rate, causing the young population to be more numerous, with the following characteristics: a) mostly in the young population group; b) the old age group is small; c) high birth rates; d) high population growth; and e) The projection of the composition of the productive age and young age in West Java Province will increase until 2030, namely 68\% of the productive age and $24 \%$ of the young age [14]. The West Java Provincial BKKBN carries out its duties and functions in controlling the Population Growth Rate (LPP) and creating quality families through the KB village program since 2016 . $\mathrm{KB}$ village was formed and implemented by involving community leaders, religious leaders, and communities in an area with guidance, guidance and facilitation from both the central and regional governments.

In West Java Province, the success of building community participation through the KB village has been obtained by Dusun Cigadung, Desa Karyamukti Kecamatan. Pataruman Kota Banjar The village has won the Innovative Government Award for public service at the Ministry of Home Affairs. This success is supported by the participation of the community and the contribution of various agencies in the $\mathrm{KB}$ village, considering that the full service can be felt directly by the family towards the welfare of the community.

Community participation be defined as the process by which members of the community (a) develop the capability to assume greater responsibility for assessing their needs and problems; (b) plan and then act to implement their solutions; (c) create and manage organizations in support of these efforts; and (d) evaluate the effects and bring about necessary adjustments in goals and programs on an ongoing basis. Community participation is therefore a strategy that provides people with a sense that they can solve their problems through careful reflection and collective action. This definition offers an understanding of community participation as a process of active involvement on the part of local individuals and groups in the assessment of needs, in planning solutions, in creating the structures for and implementing these solutions, and in assessing outcomes. Above all else, Zakus and Lysack understand community participation as the meaningful and substantive sharing programmatic decision making at the formulation, implementation, and evaluation phases [15].

The urgency that is emphasized in this study is the readiness of the community, especially in rural areas to face the demographic bonus, which is a condition in which a region or country has more productive age (aged 15-64 years) than the predicted non-productive age (age $65+$ ) will accelerate by $70 \%$ in 2020-2030. Thus, formulated the objectives of participation community in program of population alert village, which is implemented in the Kampung KB program.

\section{METHODS}

The research was carried out using a qualitative approach to the case study method with the intention of revealing and understanding the realities that occur in the field as they are, namely community participation in shaping the identity of a population alert village implemented in the Kampung $\mathrm{KB}$ program. The subject of this research is in Cigadung Hamlet, Pataruman District, Banjar City as a village that has won the Innovative Government Award in the field of public service at the Ministry of Home Affairs. This village has been made a KB Village because it fulfills several criteria as stipulated by the National Population and Family Planning Agency (Badan Kependudukan dan Keluarga Berencana Nasional /BKKBN).

The research was started by conducting a literature study on community empowerment and participation followed by a discussion of several experts related to social phenomena and conditions as well as an analysis that was considered a factor of urgency. Furthermore, the preparation of the grating research, instrument and process research always coincide with the data processing, so that the results of this qualitative research will continue to grow (snowball) to be able to answer the questions of research premises n carefully [16].

\section{FINDINGS AND DISCUSSION}

\section{A. Implementation of Community Empowerment through Kampung KB in Banjar City}

The camp program Kampung $\mathrm{KB}$ in Banjar underway with activities of family economic empowerment through efforts to increase the family income off (Usaha Peningkatan Pendapatan Keluarga Sejahtera, UPPKS) as well as family planning services itself. In particular, Kampung Keluarga Berencana (KKB) has a work team or the board coming from the local community. Most of the Heads of Kampung KB are also village heads or hamlet heads [17]

The Kampung KB is designed as an effort to empower communities to family planning. Its activities are managed based on the principles of, by, and for the community itself [18]. The empowerment process is designed to enable people to critically analyze their life situations and build their skills needs for activities to improve their situation. This shows that there is community support which is one of the determining factors for the success of the KB Village in Cigadung Hamlet.

The development of Kampung KB in Banjar City uses five strategies, namely: 1) the community has the ability and independence; 2) use potential resources in the transport area; 3 ) able to solve problems as well as meet community needs; 4) can improve and maintain the standard of living of the community; and 5) help build society. In principle, the KKBPK program creates a happy and prosperous small family by carrying out eight family functions. The implementation of 
family functions is expected to help a happier and more prosperous family free from poverty, ignorance and underdevelopment.

The building below is a collaboration between the Government and the community. The Municipal Government of Banjar provided a stimulant fund of five million rupiahs, while the rest was self-help. The community helps in the form of manpower, food and funds. The atmosphere can be seen on figure 1 bellow.

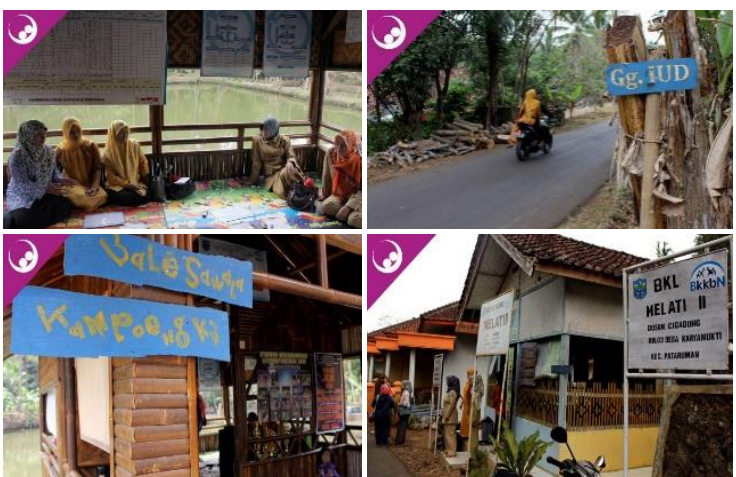

Fig. 1. The atmosphere of the Kampung KB.

This building makes it easy for the community and government to hold meetings or implement several programs. More specifically, this KB village has a requirement to achieve a contraceptive prevalence or family planning requirement of at least 65 percent with the support of family development activities, both under five (BKB), adolescents (BKR), and the elderly (BKL). These activities are actively managed by $\mathrm{KB}$ cadres, KB sub post, Village KB Post, and Posyandu cadres.

\section{B. Community Participation in Kampung $K B$}

1) Community participation in planning: The community was involved in the process of starting the Kampung KB. BKKBN as the person in charge of the program always involves the community at every stage until the formation of the Kampung KB. This involvement is evidenced by the existence of a building called Bale Sawala which has become the secretariat for family planning activities in Cigadung Hamlet. In addition, the community, especially women cadres, always provide suggestions regarding the family planning program to be implemented in a one year period.

Family planning extension workers and the community always coordinate to agree on every activity to be carried out. Community involvement in this planning process makes it easier for agencies to carry out the central themes of development of population programs, family planning and family development (Keluarga Berencana, dan Pembangunan Keluarga, KKBPK). The condition of the community itself who knows better is the community so that community involvement in planning to maximize program objectives can be achieved optimally.
That way, the community can be said to be willing and aware to solve development problems in their area through Kampung KB. The Kampung KB program not only talks about limiting the high population explosion, but also seeks to empower the potential of the community to play a real role in national development.

2) Community participation in implementation: Kampung $\mathrm{KB}$ as a main population program has the aim of controlling population quantity and improving population quality as measured by an increase in family resilience and welfare. This program is in response to community needs through the implementation of cross-sector integration. Thus, not only the $\mathrm{BKKBN}$ is involved but a mix of various parties, both private and other stakeholders.

Some of the inter-sector integrated services that are the needs of the Cigadung community, for example, such as family planning services, posyandu services, population administration services (KK revisions, making ID cards or KTP), provision of reading gardens, and other services. These are activities carried out as a result of the identification of needs in the community. The introduction of Kampung KB can be seen on figure 2 bellow.

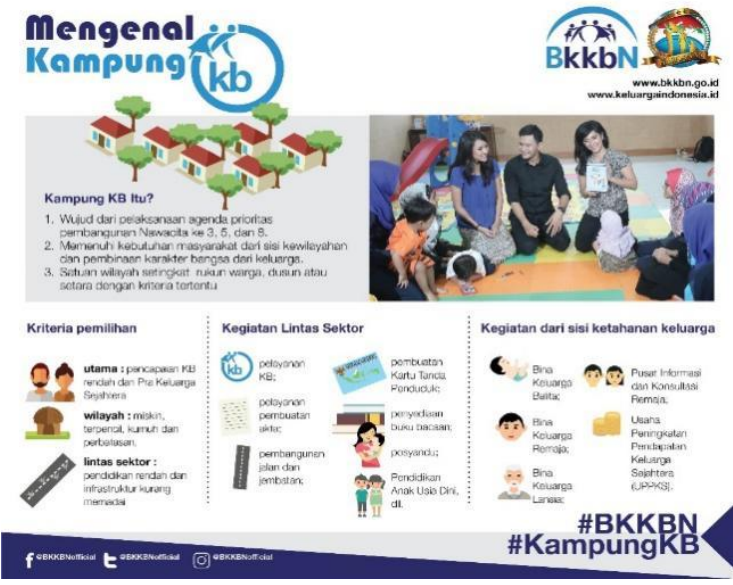

Fig. 2. The introduction of Kampung KB.

Community participation in the implementation of this program is seen from how the community can support these activities according to their needs as they should. The community can actively give their ideas to the person in charge of the program so that the quality of the program continues to improve. In addition, in the implementation of activities, the community also gives energy to organize activities so that they take place according to the desired goals and objectives. The assistance provided by the community can be in the form of ideas, manpower, funds, food, and other forms. Spontaneous involvement with awareness accompanied by responsibility for the interests of the group to achieve common goals.

3) Community participation in evaluation: The success of a program will be marked by an increase in output, as well as in terms of quantity, it can be seen how much the percentage 
of success of the program implemented, is it in accordance with the predetermined targets to achieve this, an ongoing evaluation process is required. This evaluation stage is not only carried out by the BKKBN but all parties involved, especially the community.

The community as service recipients can submit complaints and input on every ongoing program activity. The fact that the community has the courage to express their opinion means that the community actively participates in supporting the success of the program in their area.

Kampung KB tries to integrate the concept of integrated development in the fields of family planning and family welfare (KB-KS). Namely, one of the efforts to make the KBKS program a program organized from, by, and for the community. The camp u ng KB seeks to empower and provide convenience to the public to obtain total service planning program as an effort to create quality family welfare [19].

Not all villages can be entered into the family planning program, there are general criteria and specific areas selected. The main criterion is that the village has a number of poor families above the average level of the village where the village is located. Then the achievement of family planning in the village is low. As for the special criteria, inter-sectoral interventions are needed, such as inadequate educational facilities resulting in low levels of education.

Kampung Cigadung, Karyamukti Village, Pataruman Sub district, Banjar District fulfilled these criteria and the Kampung $\mathrm{KB}$ was formed as a form of community empowerment strategy. In line with the opinion [20], that efforts to empower community participation must be done in three ways, namely 1) creating an atmosphere or climate that allows the potential of the community to develop; 2) strengthening the potential or power possessed by the community by implementing concrete steps, accommodating input, and providing good facilities and infrastructure; and 3) empowering the community in the sense of protecting and defending the interests of the weak.

The three methods mentioned above are the stages that $\mathrm{KB}$ Village tries to implement with the aim of forming an identity for the standby village. The point is that the program seeks to control population quantity and improve population quality as measured by an increase in family resilience and welfare. Meanwhile, the meaning of an alert village is a village whose inhabitants have the readiness of the resources and capabilities as well as the willingness to independently prevent and overcome health problems, disasters and emergencies [2123].

Community independence is a condition experienced by the community which is characterized by the ability to think, decide and do something that is deemed appropriate in order to achieve solutions to problems faced by using their abilities [11]. This community independence can be seen in the empowerment process, with community organization approaches, participatory approaches and education for justice. These three approaches involve the community as a development subject not an object. So activities are managed based on the principles, by, and for the community itself.

In development activities and empowerment, participation is a manifestation of the awareness and concern and responsibility of the community for the importance of development aimed at improving the quality of their life, meaning that through the participation given, it means truly realizing that development activities are not just an obligation that must be carried out by the government itself but also demands community involvement which will improve their quality of life.

Participation has a very important meaning when it comes to community participation, because community participation has a very important function in governance and development, without community participation, governance and development will not run optimally. In the process, the scope of participation in empowerment and development activities there are some aspects of the scope of the engagement, namely [5,24-26]:

- participation in decision making,

- participation in the implementation of activities,

- participation in the monitoring and evaluation of activities and,

- participation in the utilization of the results of activities.

The participation carried out by the people of Cigadung Village was a type of technical participation. The community is involved in problem identification, data collection, data analysis, and implementation of activities. Participation development in this case is a tactic to involve the community in practical activities in the context of community development and empowerment. In particular, several steps can be taken to generate community participation, as expressed by Goldsmit and Blustain in Ndraha [25,26] namely:

- Participation must be done through a well-known or existing organization in the community concerned

- Participation must provide direct benefits to the community concerned

- The benefits obtained through participation can serve the interests of the local community

- In the participation process, control is guaranteed by the community.

These steps have been and are still being implemented by the $\mathrm{BKKBN}$ as the program officer with support from several other agencies / organizations.

In the end, community participation in empowerment activities is intended to give full confidence to the community in implementing empowerment programs and to provide opportunities for the community to be able to carry out these activities, as well as to develop a sense of belonging and community responsibility in implementing and developing empowerment programs. Participation is the mental 
involvement or thoughts and feelings of a person in a situation in an effort to achieve goals and take responsibility for the effort concerned. That way, the identity of the Population Alert Village can be realized as the community cares for it.

\section{CONCLUSION}

Kampung $\mathrm{KB}$ is an effort launched by the BKKBN in the context of community empowerment. Empowerment involves community participation as a subject not an object. The importance of the capacity of the community is aimed at increasing independence and internal capacity for all its resources. Thus, a model like this is very important in the empowerment process by building community initiatives to achieve independence and sensitivity to problems in their environment.

Community participation in the Kampung KB program can be seen in 3 forms of participation, namely: 1) community participation in program planning through involvement in the process of establishing Kampung KB, 2) community participation in program implementation is seen in community involvement in identifying program needs and also providing energy to organize activities to take place in accordance with the intended goals and objectives; and 3) community participation in the evaluation in the form of submitting complaints and input on any ongoing program activities

\section{ACKNOWLEDGMENT}

Thanks to the LPPM and Community Education Department for funding this research.

\section{REFERENCES}

[1] S.W. Eddyono, Women's Empowerment in Indonesia: A Poor Community in Jakarta. Routledge, 2018.

[2] L. Yang, "Empowered or disempowered? Women's participation in a development project in rural China," Asian Journal of Women's Studies, vol. 18 , no. 3, pp. 38-67, 2012.

[3] J. Cooper, "Information, Knowledge and Empowerment: The role of information in rural development," In Information Society, Springer, pp. 230-245, 1996.

[4] K. Menike, "People's empowerment from the people's perspective," Development in Practice, vol. 3, no. 3, pp. 176-183, 1993.

[5] M.H.U. Dewi, "Pengembangan desa wisata berbasis partisipasi masyarakat lokal di Desa Wisata Jatiluwih Tabanan, Bali," Jurnal Kawistara, vol. 3, no. 2, 2013

[6] Y. Hermawan and Y. Suryono, "Partisipasi masyarakat dalam penyelenggaraan program-program pusat kegiatan belajar masyarakat Ngudi Kapinteran," JPPM (Jurnal Pendidikan Dan Pemberdayaan Masyarakat), vol. 3, no. 1, pp. 97-108, 2016.
[7] R. Karsidi, "Pemberdayaan masyarakat untuk usaha kecil dan mikro (Pengalaman Empiris di Wilayah Surakarta Jawa tengah)," Jurna Penyuluhan, vol. 3, no. 2, 2007.

[8] A. Muslim, "Pendekatan Partisipatif Dalam Pemberdayaan Masyarakat," Jurnal Aplikasi Ilmu-Ilmu Agama, vol. 8, no. 2, pp. 89-103, 2007.

[9] S. Padmowihardjo, "Penyuluhan Pendamping Partisipatif," Jurna Penyuluhan, vol. 2, no. 1, 2006.

[10] I.W. Saputra, I.N. Sujana, and I.A. Haris, "Efektivitas Pengelolaan Alokasi Dana Desa (ADD) Pada Desa Lembean Kecamatan Kintamani Kabupaten Bangli Tahun 2009-2014,” Jurnal Pendidikan Ekonomi Undiksha,vol. 6, no. 1, 2016.

[11] K. Widjajanti, "Model pemberdayaan masyarakat," 2011

[12] BPS, Perkembangan Tingkat Kemiskinan Provinsi Jawa Barat September 2017. Provinsi Jawabarat: BPS Provinsi Jawabarat, 2017.

[13] BPS, Survei Penduduk Antar Sensus (SUPAS) Tahun 2015. Jakarta: Badan Pusat Statistik, 2015.

[14] Bappenas, "Pembangunan Daerah dalam Angka," 2013 [online] Retrieved from http://simreg.bappenas.go.id/document/Publikasi/DokPub/PDDA2013.p df

[15] J. Shiffman, "The construction of community participation: village family planning groups and the Indonesian state," Social Science \& Medicine Journal, vol. 54, no. 8, pp. 1199-1214, 2002.

[16] F. Guillemette, "Qualitative Research Interviewing." Loisir et Société Society and Leisure, vol. 26, no. 1, p. 273, 2003.

[17] I.D. Utomo, S.S. Arsyad, and E.N. Hasmi, "Village Family Planning Volunteers in Indonesia: Their Role in the Family Planning Programme," Reproductive Health Matters, vol. 14, no. 27, pp. 73-82, 2006

[18] P. Purnomo, A. Hufad, U. Wahyudin, A.S. Akhyadi, and D.Y. Lutfiansyah, "Needs Assessment Knowledge from Facilitator of Community Empowerment Program in the Digital Era," Journal of Nonformal Education, vol. 6, no. 2, pp. 130-138, 2020.

[19] H. Susanto and S. Mulyani, "Efektfitas Program Keluarga Berencana Metode Kontrasepsi Jangka Panjang di Kabupaten Indragiri Hilir Propinsi Riau," MAP (Jurnal Manajemen Dan Administrasi Publik), vol. 3, no. 3, pp. 370-380, 2020 .

[20] G. Kartasasmita, "Pemberdayaan masyarakat, pembangunan berbasis rakyat, angunan menuju bangsa yang maju dan mandiri," Dalam Pidato Pengukiran Guru Besar Honoris Causa Bidang Ilmu Sosial, pp. 2-5, 1995

[21] A.J. Antateliz, "Kumpulan Materi Desa Siaga," 2014.

[22] Budihardjo, Pedoman Pelaksanaan Desa Siaga di Jawa Tengah. Semarang: Kepala Dinas Kesehatan Provinsi Jawa Tengah, p. 3, 2006.

[23] Mubyarto, Strategi pembangunan pedesaan. Yogyakarta: Pusat Penelitian Pembangunan Pedesaan dan Kawasan, Universitas Gadjah Mada, 1984.

[24] J.M. Cohen and N.T. Uphoff, Rural development participation: Concepts and measures for project design implementation and evaluation. Cornell University, New York. Center for International Studies, Ithaca, NY 1977.

[25] T. Ndraha, Pembangunan masyarakat: mempersiapkan masyaraka tinggal landas. Bina Aksara, 1987.

[26] M. Totok and S. Poerwoko, Pemberdayaan Masyarakat dalam Perspektif Kebijakan Publik. Bandung: Alfabeta, 2013 